\title{
PHASE COMPOSITION OF SAMARIUM NIOBATE AND TANTALATE THIN FILMS PREPARED BY SOL-GEL METHOD
}

\author{
H. Bruncková, L. Medvecký, E. Múdra, A. Kovalčiková, J. Ďurišin, M. Šebek, \\ V. Girman
}

\begin{abstract}
Samarium niobate $\mathrm{SmNbO}_{4}(\mathrm{SNO})$ and tantalate $\mathrm{SmTaO}_{4}(\mathrm{STO})$ thin films $(\sim 100 \mathrm{~nm})$ were prepared by sol-gel/spin-coating process on alumina substrates with PZT interlayer and annealing at $1000^{\circ} \mathrm{C}$. The precursors of films were synthesized using $\mathrm{Nb}$ or Ta tartrate complexes. The improvement of the crystallinity of monoclinic $\mathrm{M}^{\prime}-\mathrm{SmTaO}_{4}$ phase via heating was observed through the coexistence of small amounts of tetragonal $\mathrm{T}$ - $\mathrm{SmTa}_{7} \mathrm{O}_{19}$ phase in $\mathrm{STO}$ precursor at $1000^{\circ} \mathrm{C}$. The XRD results of SNO and STO films confirmed monoclinic $\mathrm{M}-\mathrm{SmNbO}_{4}$ and $\mathrm{M}^{\prime}$ $\mathrm{SmTaO}_{4}$ phases, respectively, with traces of orthorhombic $\mathrm{O}-\mathrm{SmNbO}_{4}$ (in SNO). In STO film, the single monoclinic $M^{\prime}-\mathrm{SmTaO}_{4}$ phase was revealed. The surface morphology and topography of thin films were investigated by SEM and AFM analysis. STO film was smoother with roughness $3.2 \mathrm{~nm}$ in comparison with SNO (6.3 $\mathrm{nm})$. In the microstructure of SNO film, small spherical $(\sim 50 \mathrm{~nm})$ and larger cuboidal particles $(\sim 100 \mathrm{~nm})$ of the $\mathrm{SmNbO}_{4}$ phase were observed. In STO, compact clusters composed of fine spherical $\mathrm{SmTaO}_{4}$ particles $(\sim 20-50$ $n m$ ) were found. Effect of samarium can contribute to the formation different polymorphs of these films for the application to environmental electrolytic thin film devices.
\end{abstract}

Keywords: sol-gel, thin films, $\mathrm{SmNbO}_{4}, \mathrm{SmTaO}_{4}$, monoclinic phase, microstructure.

\section{INTRODUCTION}

Recently, the lanthanide $\left(\mathrm{Ln}=\mathrm{La}, \mathrm{Nd}, \mathrm{Sm}, \mathrm{Eu}\right.$ and $\mathrm{Gd}$ ) orthoniobates $\mathrm{LnNbO}_{4}$ (LnNO) and orthotantalates $\mathrm{LnTaO}_{4}$ (LnTO) materials have been developed for wide applications in satellite communication systems [1]. Samarium niobate $\mathrm{SmNbO}_{4}(\mathrm{SNO})$ and tantalate $\mathrm{SmTaO}_{4}$ (STO) films can be used as phosphors for solid-state lighting, as photocatalysts in solid-state laser materials and as ion conductors for solid oxide fuel cells. Samarium niobate $\left(\mathrm{SmNbO}_{4}\right)$ and tantalate $\left(\mathrm{SmTaO}_{4}\right)$ with fergusonite structure have attracted a great deal of attention due to their interesting physical properties, such as high dielectric constants, electro-optical, photoelastic, photocatalytic and luminescent properties as well as good mechanical and chemical stability. For SNO, there are two crystalline forms, the low temperature M-phase isostructural with monoclinic form of the fergusonite and the high temperature T-phase corresponding to tetragonal scheelite. The transition between two phases occurs reversibly in the range $500-800^{\circ} \mathrm{C}$ [2]. STO crystallizes in monoclinic form, besides its ability to possess two fergusonite-type structures, first known as M-type (I2/a) and second called $\mathrm{M}^{\prime}$-type (P2/a) [1,2].

\footnotetext{
Helena Bruncková, Lubomír Medvecký, Erika Múdra, Alexandra Kovalčiková, Juraj Durišin, Martin Šebek,
} Vladimír Girman: Institute of Materials Research, Slovak Academy of Sciences, Košice, Slovak Republic 
Formation of these structure types depends on the atomic radius of $\mathrm{Ln}$ and synthesis conditions. $\mathrm{LnNbO}_{4}$ and $\mathrm{LnTaO}_{4}$ precursors of thin films can be prepared by different methods: conventional solid state reaction (SSR) [3], hydrothermal [4] and sol-gel [1] methods. LnNO and LnTO ceramics were prepared by SSR and sintered at 1300$1 \overline{4} 00^{\circ} \mathrm{C} . \mathrm{SmNbO}_{4}$ ceramics were annealed at $1200-1300^{\circ} \mathrm{C}$ with monoclinic and tetragonal structure [5,6]. Polycrystalline $\mathrm{SmTaO}_{4}$ were heating at $1400^{\circ} \mathrm{C}$ with single monoclinic $\mathrm{M}$ and $\mathrm{M}^{\prime}$-type structure [7,8], respectively.

The sol-gel method has been used to prepare $\mathrm{LnNbO}_{4}$ and $\mathrm{LnTaO}_{4}$ at low temperature [1]. Because both LnNO and LnTO crystallize at 600 and $800^{\circ} \mathrm{C}$, respectively in the same metastable fluorite tetragonal $\mathrm{T}^{\prime}$ structure (similar to that of tetragonal zirconia, $\mathrm{t}-\mathrm{ZrO}_{2}$ ) also initially might transform to stable $\mathrm{M}-\mathrm{LnNbO}_{4}$ at $800^{\circ} \mathrm{C}$ and $\mathrm{M}^{\prime}-\mathrm{LnTaO}_{4}$ at $900^{\circ} \mathrm{C}$ [1]. $\mathrm{T}^{\prime}$ structure is the first crystalline product. $\mathrm{SmNbO}_{4}$ polycrystalline powders were obtained by polymeric sol-gel process and metastable fluorite phase was identified in the synthetized powders. After sintering process at $1300^{\circ} \mathrm{C}$, single monoclinic phase was obtained [9]. $\mathrm{SmNbO}_{4}$ thin films, prepared by the sol-gel method on Si substrates during crystallization at $900-1200^{\circ} \mathrm{C}$ exhibited polycrystalline microstructure [10]. Considering the primary electrical behaviours of $\mathrm{SNO}$, the chip capacitor based on $\mathrm{SmNb}_{4}$ shows promise for future semiconductor device application.

Thin films-solid oxide fuel cells (TF-SOFCs) with thin films of electrolytes have attracted a considerable attention due to their high energy conversion efficiency and fuel flexibility. In the search for new materials, acceptor substituted lanthanide orthoniobates and orthotantalates $\mathrm{Sm}(\mathrm{Nb} / \mathrm{Ta}) \mathrm{O}_{4}$ oxides were recently demonstrated to exhibit appreciable proton conductivity in wet atmospheres $[11,12]$. Electrolyte thin films of TF-SOFCs must be continuous and crack-free in order to prevent gas leakage, and must rest between two porous electrodes through which gases can pass freely to or away from the active sites for electrochemical reactions near the electrode-electrolyte interface [13]. The proton conductivity of $\mathrm{SmNbO}_{4}$ and $\mathrm{SmTaO}_{4}$ thin films materials reaches values of the order of $10^{-1} \mathrm{~S} \mathrm{~cm}^{-1}$ and have interesting for hydrogen and humidity sensors at temperatures below around $700^{\circ} \mathrm{C}$.

Recently, several groups published studies on the relationship between electrical behavior and phase and crystallographic orientation by the introduction of buffer layers such as $\mathrm{SrRuO}_{3}, \mathrm{LaNiO}_{3}, \mathrm{SrTiO}_{3},(\mathrm{La}, \mathrm{Sr}) \mathrm{MnO}_{3},(\mathrm{La}, \mathrm{Sr}) \mathrm{CoO}_{3}$ is effective method to improve properties of thin films [14,15]. The significant impact of $\mathrm{SrTiO}_{3}$ [14] or $(\mathrm{La}, \mathrm{Sr}) \mathrm{CoO}_{3}[15]$ acting as buffer layers on structural, microstructural and ferroelectric

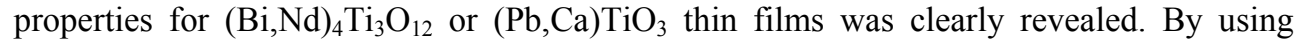
$\mathrm{PbTiO}_{3}$ and $\left(\mathrm{Pb}_{0.72} \mathrm{La}_{0.28}\right) \mathrm{TiO}_{3}$ or $\mathrm{Pb}\left(\mathrm{Zr}_{0.52} \mathrm{Ti}_{0.48}\right) \mathrm{O}_{3}$ (PZT) interlayer it was possible to control the PZT film orientation [16,17]. Sintering temperature has a pronounced effect on the stability of perovskite $\mathrm{Pb}\left(\mathrm{Zr}_{0.52} \mathrm{Ti}_{0.48}\right) \mathrm{O}_{3}$ phase in PZT $[18,19]$. High temperatures $\left(1000^{\circ} \mathrm{C}\right)$ favor the $\mathrm{ZrO}_{2}$ and pyrochlore $\mathrm{Pb}_{0.75}\left(\mathrm{Zr}_{1.5} \mathrm{Ti}_{0.5}\right) \mathrm{O}_{\mathrm{x}}$ or $\mathrm{Pb}_{1.2}\left(\mathrm{Zr}_{1.2} \mathrm{Ti}_{0.8}\right) \mathrm{O}_{\mathrm{x}}$ phase [20]. Monoclinic $\mathrm{ZrO}_{2}$ phase forms as a result of $\mathrm{PbO}$ loss at the sample surface ( $\mathrm{PbO}$ melts at $880^{\circ} \mathrm{C}$ ). The formation of a $\mathrm{Pb}$-deficient fluorite or pyrochlore phase during processing is not the disaster that it was always thought to be. In fact, for the fabrication of ultrathin films with thicknesses of $10-50 \mathrm{~nm}$, it is beneficial to deliberately form the Pb-deficient fluorite during initial processing steps in order to minimize electrode interactions [21].

In this work, we demonstrate a method to prepare novel $\mathrm{SmNb}_{4}(\mathrm{SNO})$ and $\mathrm{SmTaO}_{4}$ (STO) thin films from polymeric $\mathrm{Nb}$ and Ta-tartrate solutions by sol-gel/spincoating process. The precursors of films were analysed by DSC/TG, XRD, Raman, SEM, TEM and AFM. We also report the structural properties and morphology of SNO and STO thin films deposited on the alumina substrates with PZT interlayer and annealed at $1000^{\circ} \mathrm{C}$. 
The results of this work can contribute to the fabrication of these films for the application to environmental electrolytic thin film devices.

\section{EXPERIMENTAL}

$\mathrm{SmNbO}_{4}$ and $\mathrm{SmTaO}_{4}$ precursors were prepared by modified polymeric complex sol-gel method [22]. The novel SNO or STO sol precursors were synthesized from $\mathrm{Sm}\left(\mathrm{NO}_{3}\right)_{3} \cdot \mathrm{xH}_{2} \mathrm{O}$ and $\mathrm{Nb}$ - or Ta-tartrate complex in solvent (ethylene glycol) with molar ratio of $\mathrm{Sm} / \mathrm{Nb}$ or $\mathrm{Sm} / \mathrm{Ta}=1 / 1$. The $\mathrm{Sm}\left(\mathrm{NO}_{3}\right)_{3} \cdot \mathrm{xH}_{2} \mathrm{O}$ solutions were prepared by the dissolution of $\mathrm{Sm}_{2} \mathrm{O}_{3}$ in $\mathrm{HNO}_{3}$ at $50^{\circ} \mathrm{C}$. All chemicals were of analytical grade and were purchased from Merck (Darmstadt, Germany). After homogenization at $80^{\circ} \mathrm{C}$, the solutions were stirred, heated at $130^{\circ} \mathrm{C}$ for 5 hours with the formation of transparent viscous sols. Basic $(0.5 \mathrm{M})$ sols were diluted in stabilization solution (n-propanol). The sols remained stable at room temperature for two months. $\mathrm{Pb}\left(\mathrm{Zr}_{0.52} \mathrm{Ti}_{0.48}\right) \mathrm{O}_{3}$ (PZT) sol was prepared by sol-gel method [23]. The SNO and STO yellow gels were obtained after drying at $135^{\circ} \mathrm{C}$ for 12 hours. The final powder precursors were annealed at $1000{ }^{\circ} \mathrm{C}$ for 1 hour.

SNO and STO thin films were prepared from the adequate sols synthesized in the stoichiometric ratio and deposited on alumina substrates. Polycrystalline alumina wafer (50.8 $\mathrm{mm} \times 50.8 \mathrm{~mm} \times 0.63 \mathrm{~mm}$ and $630 \mu \mathrm{m}$ thickness) was used to deposit the films. The alumina substrates were spin-coated with PZT sol precursor at $2000 \mathrm{rpm}$ for $30 \mathrm{~s}$ (PZT interlayer) and dried at $110^{\circ} \mathrm{C}$ for $3 \mathrm{~min}$. Single SNO or STO film layer were deposited on $\mathrm{PZT} / \mathrm{Al}_{2} \mathrm{O}_{3}$ substrate with a drying step at $110^{\circ} \mathrm{C}$ for $3 \mathrm{~min}$ and calcined at $400^{\circ} \mathrm{C}$ for 3 min. The coating cycling was repeated three times to obtain three layers of thin films. Final 3layered SNO and STO films were annealed at $1000^{\circ} \mathrm{C}$ for 1 hour in air.

The thermal decomposition of gels were analysed by differential scanning calorimetry, thermogravimetric analysis (JUPITER STA 449-F1 NETZSCH). The chemical composition of samples were analysed from Raman spectra were collected by a Raman spectroscopy (HORIBA BX 41TF). The phase composition of precursors and films was determined by X-ray diffraction analysis (XRD), (a model X' Pert Pro, Philips, The Netherlands) using $\mathrm{CuK}_{\alpha}$ radiation. The surface of SNO and STO powder morphologies were characterized using scanning electron microscope (SEM), (JSM-7000F, Jeol, Japan) equipped with an energy dispersive X-ray (EDX) analyser link ISIS (Oxford, UK) and transmission electron microscopy (TEM), JEOL (JEM 2100F) equipped with the addition of EDS analysis. The surface and cross-section of film microstructures were characterized using SEM equipped with focused ion beam (FIB-SEM), (Auriga Compact, Carl Zeiss Germany). Cross sections of films were opened to observation after cutting with the focused $\mathrm{Ga}^{+}$ion beam and removing of a small piece of film layer from substrate. Surface topography and root mean square roughness of films were characterized by atomic force microscopy (AFM, Dimension ICON, by Veeco Instruments).

\section{RESULTS AND DISCUSSION}

The XRD diffractograms of SNO and STO precursors after annealing between $600-1200^{\circ} \mathrm{C}$ are shown in Fig. 1. The XRD patterns verified the formation of $\mathrm{SmNbO}_{4}$ : amorphous $\left(600-700^{\circ} \mathrm{C}\right)$, orthorhombic $\mathrm{O}\left(800^{\circ} \mathrm{C}\right)$, and coexistence of orthorhombic and monoclinic $\mathrm{M}\left(1000-1200^{\circ} \mathrm{C}\right)$ phases, which correspond to $\mathrm{O}_{-} \mathrm{SmNbO}_{4}$ (JCPDS no. 722143) and ${\mathrm{M}-\mathrm{SmNbO}_{4}}_{4}$ (22-1303) in SNO powders (Fig. 1a). The presence of $\mathrm{SmTaO}_{4}$ : amorphous $\left(700-800^{\circ} \mathrm{C}\right)$, fluorite $\mathrm{T}^{\prime}\left(900^{\circ} \mathrm{C}\right)$, tetragonal $\mathrm{T}\left(1000-1100^{\circ} \mathrm{C}\right)$ and coexistence of tetragonal and monoclinic $\mathrm{M}^{\prime}\left(1200^{\circ} \mathrm{C}\right)$ phases denoted as $\mathrm{T}-\mathrm{SmTa}_{7} \mathrm{O}_{19}(23-0626)$ and $\mathrm{M}^{\prime}-\mathrm{SmTaO}_{4}$ (24-1010) were identified in STO powders (Fig. 1b). The $\mathrm{T}^{\prime}$ formation of metastable phase with fluorite structure is similar to the tetragonal zirconia $\left(\mathrm{t}-\mathrm{ZrO}_{2}\right)$ 
reported by Mather and Davies $[1,24,25]$. As resulted from the XRD analysis, the annealing temperature for the preparation of $\overline{\mathrm{SmNbO}}_{4}$ and $\mathrm{SmTaO}_{4}$ phases was remarkably decreased to $1000-1200^{\circ} \mathrm{C}$ and it was lower than in conventional mixed route $\left(1400-1500^{\circ} \mathrm{C}\right.$ for 10 hours) [3].

TG and DSC curves of samarium niobate and tantalate xerogels heated to $1300^{\circ} \mathrm{C}$ in air are shown in Fig. 2a. The small $6 \%$ weight losses at temperatures up to $200^{\circ} \mathrm{C}$ are due to evaporation of water residuals and etylene glycol. It was shown that all chemical reactions involving weight losses, such as decomposition of organic polymeric network, finished below $500^{\circ} \mathrm{C}$. In Fig. $2 \mathrm{a}$, the exothermic peaks at 276,315 and $360^{\circ} \mathrm{C}$ (SNO) and $324^{\circ} \mathrm{C}$ (STO) could be attributed to the thermal decomposition of tartrate complexes with corresponding weight losses about 43\% (SNO) and 60\% (STO). The formation of amorphous oxides started above $400^{\circ} \mathrm{C}$ with a small exo-effects. The region between 450 and $600^{\circ} \mathrm{C}$ is the result of the combustion of residual carbon and following crystallization of $\mathrm{SmNbO}_{4}$ phase at $640^{\circ} \mathrm{C}$ (fluorite tetragonal phase unknown structure denoted as $\mathrm{T}^{\prime}$ when it is prepared from amorphous) [1]. The exothermic effect above $889^{\circ} \mathrm{C}$ (SNO) corresponds to the transformation from $\overline{\mathrm{T}}^{\prime}$ to the stable $\mathrm{T}$ or $\mathrm{M}$ phase. In DSC curve of $\mathrm{SNO}$, broad and distinct endothermic peak above $1100^{\circ} \mathrm{C}$ (SNO) characterize the T-M transformation of $\mathrm{SmNbO}_{4}$. The two small exothermic peaks at $890^{\circ} \mathrm{C}$ and $964^{\circ} \mathrm{C}$ (STO) were observed. The first exo-peak is represents crystallization of $\mathrm{T}^{\prime}$ phase and the second correspond with the residual carbon oxidation. The next exothermic peaks at $1162^{\circ} \mathrm{C}$ (STO) related to transformation from metastable $\mathrm{T}^{\prime}$ structure to $\mathrm{T}$ or $\mathrm{M}^{\prime}$ phase. The last approximately 5-9 \% weight loss on TG curve between 900 to $1300^{\circ} \mathrm{C}$ relates to above transformations. On basis of TG analysis, the total weight losses weres about $55 \%$ (SNO) and $70 \%$ (STO). Raman spectra of precursors after annealing at $1000^{\circ} \mathrm{C}$ are shown in Fig. 2b. 18 optical Raman active phonon modes are expected [26,27]. The phonons between $400-500 \mathrm{~cm}^{-1}$ and $\sim 600-700 \mathrm{~cm}^{-1}$ are assigned to anti-symmetric Nb-O vibrations, while the main modes $\left(\mathrm{A}_{\mathrm{g}}\right.$ and $\left.\mathrm{B}_{\mathrm{g}}\right)$ at approximately 330 and $810 \mathrm{~cm}^{-1}$ are related to the symmetric $\mathrm{Nb}-\mathrm{O}$ vibrations of the $\mathrm{NbO}_{4}$ tetrahedron [28] in $\mathrm{SmNbO}_{4}$ precursor annealed at $1000^{\circ} \mathrm{C}$ (Fig. 2b). The peaks around 375 and $805 \mathrm{~cm}^{-1}$ (STO) represent the tetragonal T-SmTa $\mathrm{O}_{19}$ derived from fluorite structure $\mathrm{T}^{\prime}$-type $\mathrm{SmTaO}_{4}$ [3]. The peaks around 330 and $800 \mathrm{~cm}^{-1}$ in $\mathrm{SmTaO}_{4}$ precursor at $1000^{\circ} \mathrm{C}$ represent the tetragonal $\mathrm{T}-\mathrm{SmTa}_{7} \mathrm{O}_{19}$ structure. The possible reaction (1) in SNO and (2) in STO describe the formation of $\mathrm{SmNbO}_{4}$ and $\mathrm{SmTaO}_{4}$ phases, derived from DSC/TG curves, XRD patterns and Raman spectra.

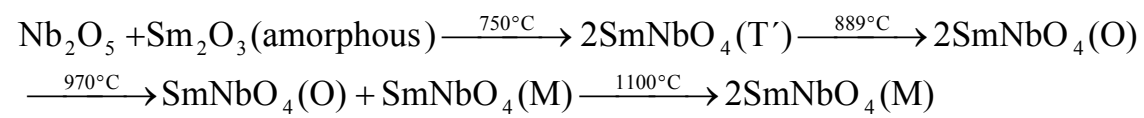

$$
\begin{aligned}
& \mathrm{Ta}_{2} \mathrm{O}_{5}+\mathrm{Sm}_{2} \mathrm{O}_{3} \text { (amorphous) } \stackrel{770^{\circ} \mathrm{C}}{\longrightarrow} 2 \mathrm{SmTa}_{7} \mathrm{O}_{19}\left(\mathrm{~T}^{\prime}\right) \stackrel{964^{\circ} \mathrm{C}}{\longrightarrow} 2 \mathrm{SmTa}_{7} \mathrm{O}_{19}(\mathrm{~T}) \\
& \stackrel{1050^{\circ} \mathrm{C}}{\longrightarrow} 2 \mathrm{SmTa}_{7} \mathrm{O}_{19}(\mathrm{~T})+\mathrm{SmTaO}_{4}\left(\mathrm{M}^{\prime}\right) \stackrel{1162^{\circ} \mathrm{C}}{\longrightarrow} \operatorname{SmTaO}_{4}\left(\mathrm{M}^{\prime}\right)
\end{aligned}
$$



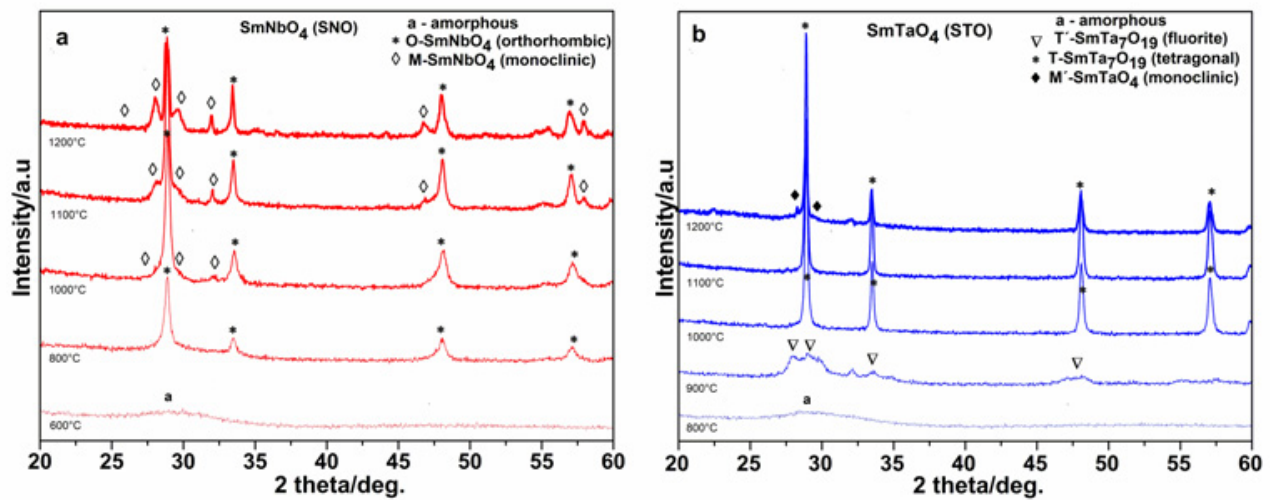

Fig.1. XRD patterns of (a) SNO and (b) STO precursors annealed at $600-1200^{\circ} \mathrm{C}$.
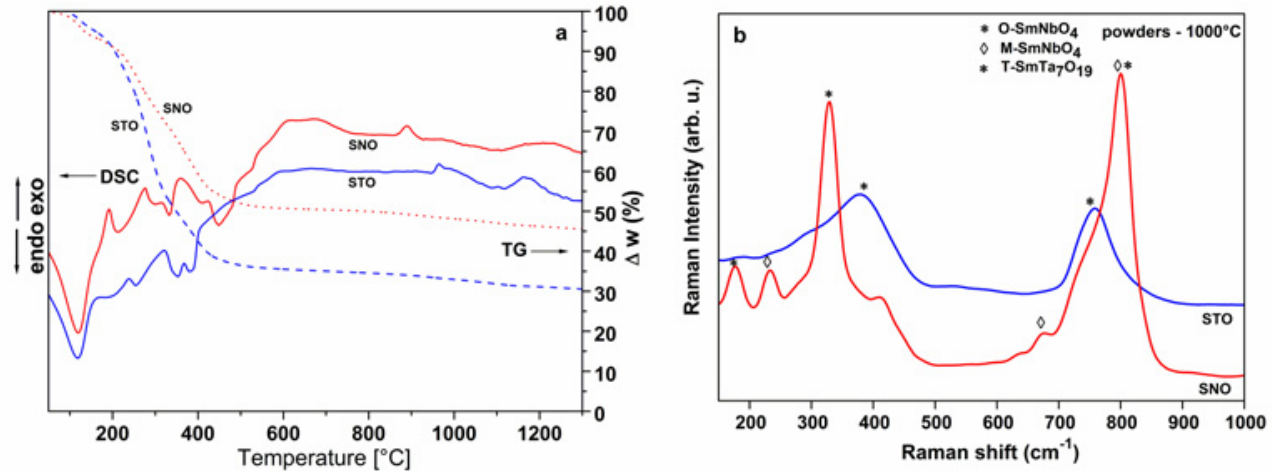

Fig.2. (a) DSC and TG curves of SNO and STO gel precursors and (b) Raman spectra of SNO and STO precursors after annealing at $1000^{\circ} \mathrm{C}$.

The particle morphology in SNO and STO precursors prepared at different temperatures were investigated by SEM and TEM (Fig. 3). The micrographs of the SNO precursors at $800^{\circ} \mathrm{C}$ for 1 hour (Fig. 3a) demonstrate formation of the extremely fine particles $(\sim 20 \mathrm{~nm})$ connected into large agglomerates (HRTEM image of $\mathrm{T}^{\prime}-\mathrm{SmNbO}_{4}$ ). After annealing at $1000^{\circ} \mathrm{C}$ for 1 hour, the spherical particle coarsening to size around $50-80$ $\mathrm{nm}$ and cuboidal 100-150 $\mathrm{nm}$ in SNO (Fig. 3c) was observed. In Fig. 3b,d, the morphologies of particle agglomerates after annealing of STO samples at 800 and $1000^{\circ} \mathrm{C}$ are shown. In amorphous STO powders (Fig. 3b), particle agglomerates (up to $1 \mu \mathrm{m}$ size) with a more compact irregular morphology and plate-like shape $\left(\mathrm{T}^{\prime}-\mathrm{SmTa}_{7} \mathrm{O}_{19}\right)$ were identified [29]. They were consisted of small approximately $100 \mathrm{~nm}$ globular clusters with very fine structure. On other side, in STO after annealing at $1000^{\circ} \mathrm{C}$, the large particles (T$\mathrm{SmTa}_{7} \mathrm{O}_{19}$ ) with the shape of leaves or flakes mixed with smaller particles can be visible (Fig. 3d). The particles were formed from highly coalesced spherical particles with diameter $\sim 50-100 \mathrm{~nm}[9,30,31]$. The SEM/EDX analyses of SNO and STO powders at $1000^{\circ} \mathrm{C}$, respectively are shown in Fig. 3e,f. The calculated $\mathrm{Sm} / \mathrm{Nb}$ and $\mathrm{Sm} / \mathrm{Ta}$ atomic ratio were approximately 1.0. (spectrum 1 and 2 ). 

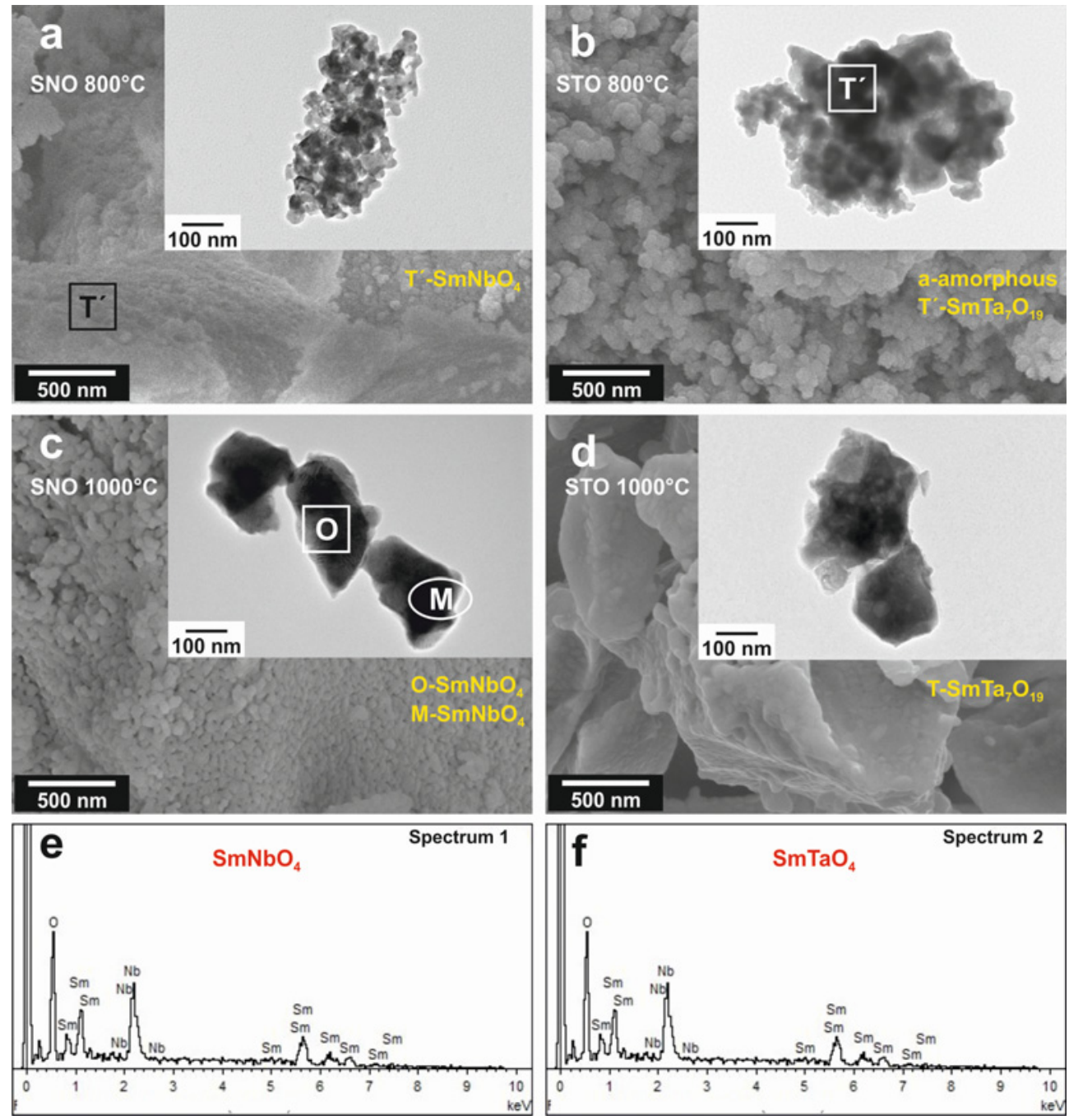

Fig.3. SEM and TEM surface morphologies of (a) SNO, (b) STO at $800^{\circ} \mathrm{C}$, (c) SNO, (d) STO powders after annealing at $1000^{\circ} \mathrm{C}$ and EDX spectra of (e) $\mathrm{SmNbO}_{4}$ and (f) $\mathrm{SmTaO}_{4}$.

Fig. 4a shows XRD patterns of SNO and STO films annealed at $1000^{\circ} \mathrm{C}$. XRD analyses verified formation of the phases: $\mathrm{O}-\mathrm{SmNbO}_{4}(72-2143)$ and $\mathrm{M}^{-} \mathrm{SmNbO}_{4}$ (221303) in SNO. Samarium tantalate usually crystallize in three different structures at room temperature [30,32]. One belongs to I2/a symmetry or M-type (fergusonite structure), the other is $\mathrm{P} 2 / \mathrm{a}$ symmetry or $\mathrm{M}^{\prime}$-type, which is true equilibrium phase at room temperature with the M-type modification and another is the high temperature tetragonal phase of the scheelite structure or T-type. As illustrated in Fig. 4a, the STO film is composed of single $\mathrm{M}^{\prime}-\mathrm{SmTaO}_{4}$ (24-1010). From XRD patterns resulted that the tetragonal phase transforms to monoclinic M or M'phase in SNO or STO films, respectively. 

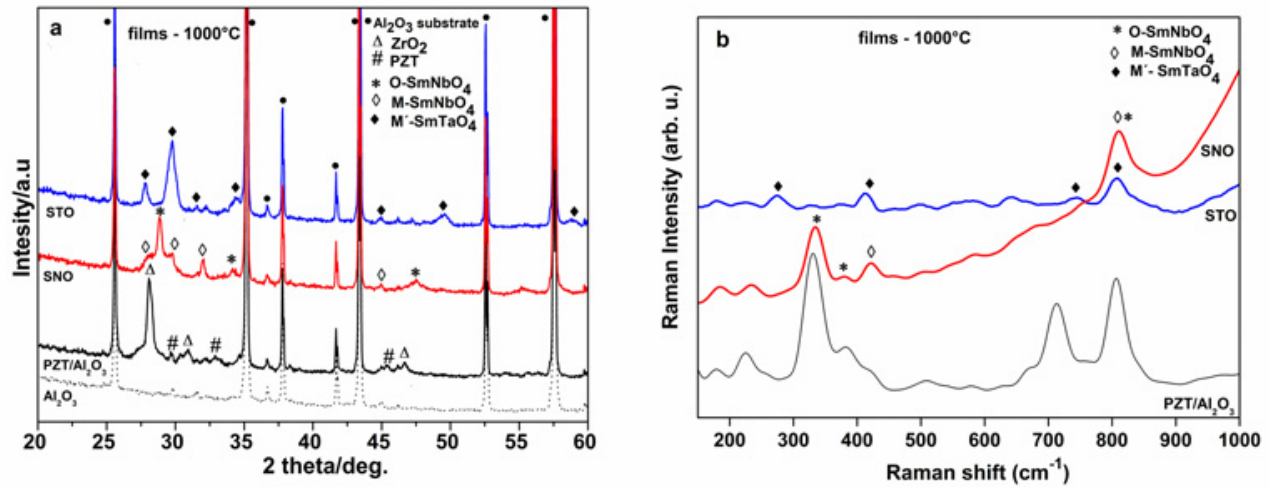

Fig.4. (a) XRD patterns and (b) Raman spectra of $\mathrm{SmNbO}_{4}$ and $\mathrm{SmTaO}_{4}$ thin films on $\mathrm{PZT} / \mathrm{Al}_{2} \mathrm{O}_{3}$ substrates after annealing at $1000^{\circ} \mathrm{C}$.
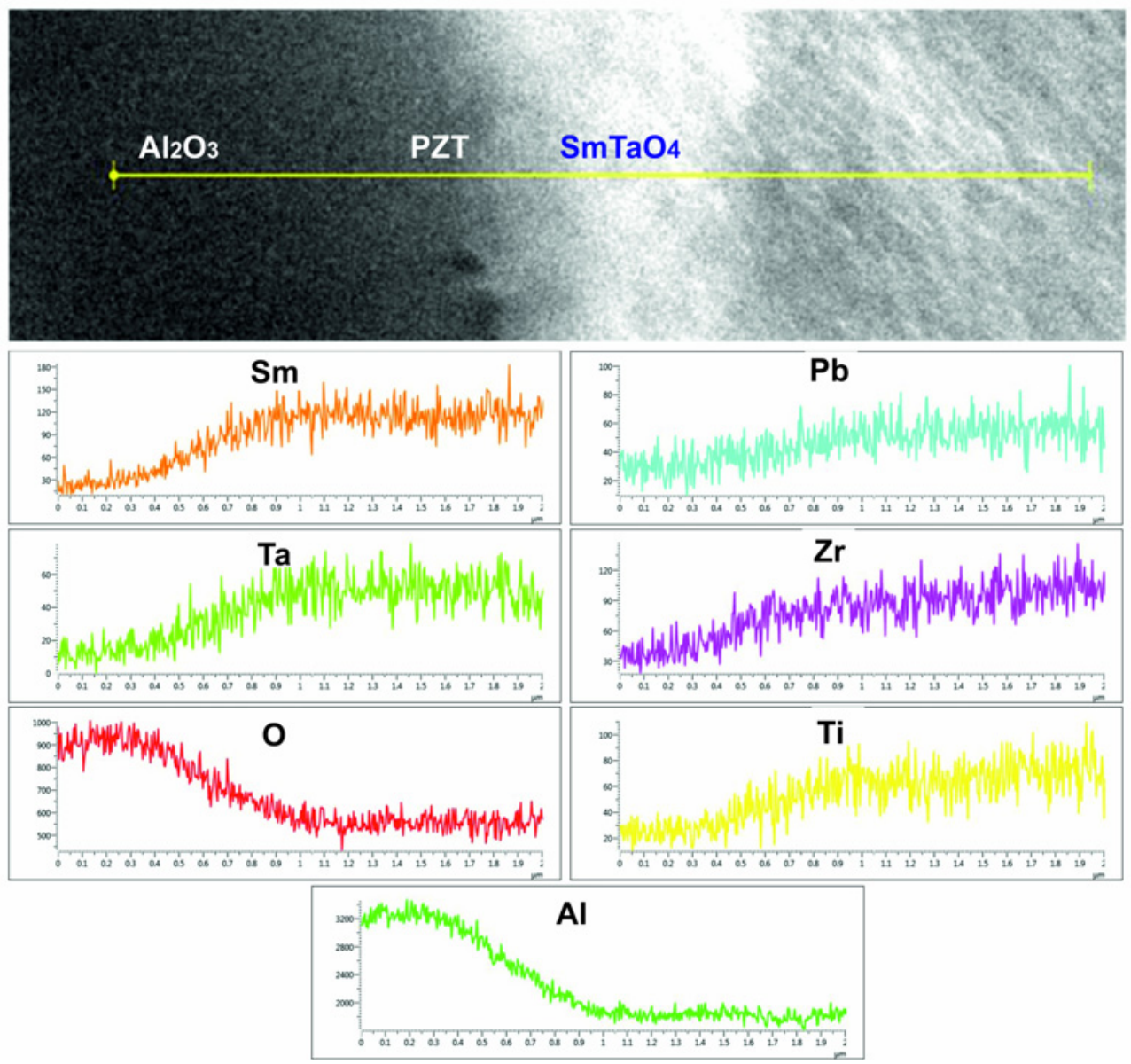

Fig. 5. FIB-SEM cross-section microstructure and EDS lines of $\mathrm{SmTaO}_{4}$ thin films. 
The XRD pattern at $1000^{\circ} \mathrm{C}$ shows the presence of the monoclinic $\mathrm{ZrO}_{2}$ phase (JCPDS 83-0944) and pyrochore PZT phase and this may be due to the melting of $\mathrm{PbO}$ at high temperature in PZT interlayer on substrate $\mathrm{Al}_{2} \mathrm{O}_{3}$. For the pyrochore phase the only pattern found in the database was JCPDS 26-0142 corresponding to $\mathrm{Pb}_{2} \mathrm{Ti}_{2} \mathrm{O}_{6}$. The actual composition of the pyrochlore phase in sol-gel prepared films is $\mathrm{Pb}_{2.5}\left(\mathrm{Zr}_{0.51} \mathrm{Ti}_{0.49}\right)_{2} \mathrm{O}_{6.2}$ [33]. Pyrochlore $\mathrm{Pb}_{2}(\mathrm{Zr}, \mathrm{Ti})_{2} \mathrm{O}_{7}$ phase occurs at $2 \theta$ equal to $29^{\circ}(222), 33^{\circ}(400)$ and $45^{\circ}(200) 2 \theta$ (one PZT layer - only $50 \mathrm{~nm}$ thickness) [34]. Raman spectra of films after annealing at $1000^{\circ} \mathrm{C}$ are shown in Fig. 4b. Two dominant bands at $330 \mathrm{~cm}^{-1}$ and $800-805 \mathrm{~cm}^{-1}$ were clearly identified in all films. These bands are assigned to the bending and stretching modes of $\mathrm{MO}_{6}\left(\mathrm{M}=\mathrm{Nb}^{5+}, \mathrm{Ta}^{5+}\right)$ octahedron, respectively. Frequencies in range $230-450 \mathrm{~cm}^{-1}$ are influenced by $\mathrm{Sm}^{3+}$ cation displacements. $550-850 \mathrm{~cm}^{-1}$ range could be assigned to the $\mathrm{Nb}$ $\mathrm{O}$ or Ta-O stretching modes essentially involving oxygen atom shifts [26].

The cross-section microstructures of STO (Fig. 5) thin film deposited on $\mathrm{PZT} / \mathrm{Al}_{2} \mathrm{O}_{3}$ substrates with EDS lines analysis were characterized using SEM equipped with focused ion beam (FIB). From image analysis of STO films resulted that the STO and PZT film thickness was $\sim 100$ and $50 \mathrm{~nm}$, respectively. EDS analysis ( $\mathrm{Sm}, \mathrm{Ta}, \mathrm{O}, \mathrm{Pb}, \mathrm{Zr}$, Ti and $\mathrm{Al}$ ) demonstrate the distribution of elements across $\mathrm{STO}$ film and $\mathrm{PZT} / \mathrm{Al}_{2} \mathrm{O}_{3}$ substrate.
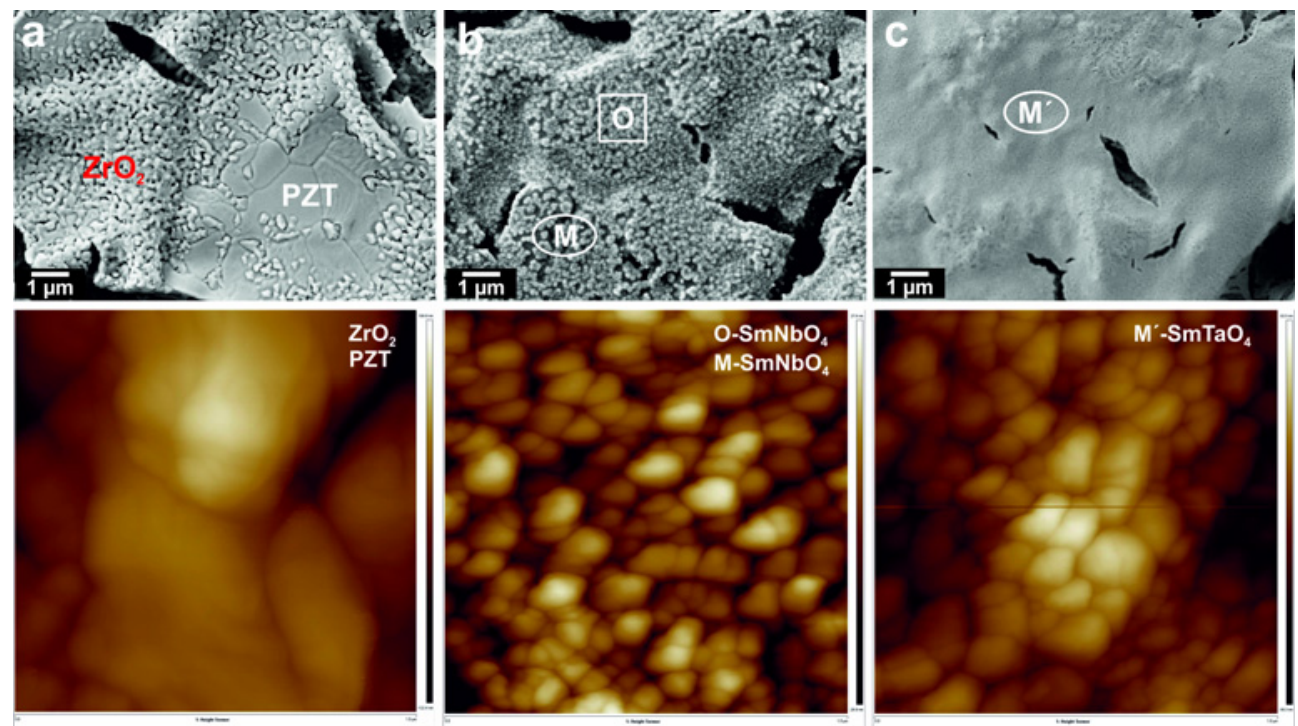

Fig.6. SEM surface microstructure and 2D AFM topography of (a) $\mathrm{PZT} / \mathrm{Al}_{2} \mathrm{O}_{3}$ substrates,

(b) SNO and (c) STO thin films.

Fig. 6 demonstrates the SEM and 2D AFM micrographs of PZT interlayer on $\mathrm{Al}_{2} \mathrm{O}_{3}$ substrate, $\mathrm{SNO}$ and STO films. The PZT film microstructure (Fig. 6a) contained two phases (monoclinic $\mathrm{ZrO}_{2}$ and pyrochlore $\left.\mathrm{Pb}_{2.5}\left(\mathrm{Zr}_{0.51} \mathrm{Ti}_{0.49}\right)_{2} \mathrm{O}_{6.2}\right)$. It is generally observed in sol-gel prepared film that a film annealed at low temperature $350^{\circ} \mathrm{C}$ and $420^{\circ} \mathrm{C}$ has amorphous and pyrochlore structure, respectively [35]. The crystallinity increases and the pyrochlore structure transforms to the perovskite structure during annealing at $500^{\circ} \mathrm{C}$. Films annealed between 500 and $800^{\circ} \mathrm{C}$ consisted mainly of the perovskite phase and some $\mathrm{PbO}$, $\mathrm{ZrO}_{2}$, and pyrochlore as minor phases. The residual pyrochlore phase was relatively stable 
in this temperature range, whereas $\mathrm{PbO}$ and $\mathrm{ZrO}_{2}$ disappeared between 700 and $800^{\circ} \mathrm{C}$ the optimal temperature region. Annealing of films above $800^{\circ} \mathrm{C}$ led to decomposition reactions. $\mathrm{ZrO}_{2}$ precipitated at around $900-1000^{\circ} \mathrm{C}$ due to an evaporation of lead and the perovskite $\mathrm{Pb}\left(\mathrm{Zr}_{0.52} \mathrm{Ti}_{0.48}\right) \mathrm{O}_{3}$ phase convert to the pyrochlore $\mathrm{Pb}_{2.5}\left(\mathrm{Zr}_{0.51} \mathrm{Ti}_{0.49}\right)_{2} \mathrm{O}_{6.2}$ phase and monoclinic $\mathrm{ZrO}_{2}[21,35]$. The stability of pyrochlore may be attributed to its ability to exist in a range of pyrochlore structure can vary within a certain range, as a result of which the phase can be enriched or depleted in lead. The pyrochlore phase has also been found at different ratios of $\mathrm{Zr} / \mathrm{Ti}$. The apparent reasons for the decomposition reactions and the formation of pyrochlore PZT are the loss of lead by evaporation and the diffusion of aluminum from the substrate into the film. The evaporation results in a deficiency of lead in a PZT lattice. PZT film was completely decomposed at $1100^{\circ} \mathrm{C}\left(\mathrm{ZrO}_{2}, \mathrm{TiO}_{2}\right.$ and residual $\mathrm{PbO}$ ) a process compounded by diffusion reactions [35]. The SEM and 2D AFM micrographs of the SNO thin film are shown in Fig. 6b. It was observed that the particles in the ceramic films were closely packed and uniformly distributed at $1000^{\circ} \mathrm{C}$. The microstructure of SNO film composed of $\mathrm{SmNbO}_{4}$ was smoother than PZT film. Contrary to above the surface SNO film was rougher and more heterogeneous as compared with STO. The heterogeneous microstructure of the SNO is characterized by the bimodal particle size distribution and contains smaller spherical orthorhombic $\mathrm{SmNbO}_{4}(\sim 30-50 \mathrm{~nm})$ and coarser cuboidal monoclinic $\mathrm{SmNbO}_{4}$ particles of about $\sim 100 \mathrm{~nm}$. The homogeneous surface of STO film (Fig. 6c) composed of $\mathrm{SmTaO}_{4}$ spherical particles ( $\left.\sim 50 \mathrm{~nm}\right)$. As shown in Fig. 6b, the AFM image illustrates that average particle size $(\sim 50-100 \mathrm{~nm})$ correspond to the size of $\mathrm{SmNbO}_{4}$ particles in SNO film and it is evidently larger than that in STO film ( $20-50 \mathrm{~nm})$. The root mean square $\left(R_{q}\right)$ surface roughness values of the films $\left(1 \times 1 \mu^{2}\right)$ were calculated as $6.35 \mathrm{~nm}$ for SNO films, $3.23 \mathrm{~nm}$ for STO film and $24 \mathrm{~nm}$ for PZT layer on $\mathrm{Al}_{2} \mathrm{O}_{3}$ substrate. The structural properties of SNO and STO films depend on their phase composition.

\section{CONCLUSIONS}

In conclusion, we have developed novel samarium niobate $\mathrm{SmNbO}_{4}(\mathrm{SNO})$ and samarium tantalate $\mathrm{SmTaO}_{4}$ (STO) thin films using tartrate solutions. The different mechanism of the phase transformation in heating SNO and STO precursors from fluorite (at 800 and $900^{\circ} \mathrm{C}$, respectively) via orthorhombic $\mathrm{SmNbO}_{4}$ (at $900^{\circ} \mathrm{C}$ ) and tetragonal $\mathrm{SmTa}_{7} \mathrm{O}_{19}$ phase (at $1000^{\circ} \mathrm{C}$ ) to monoclinic $\mathrm{M}-\mathrm{SmNbO}_{4}$ (at $1000^{\circ} \mathrm{C}$ ) or $\mathrm{M}^{\prime}-\mathrm{SmTaO}_{4}$ (at $1100^{\circ} \mathrm{C}$ ) was determined.

The ceramic SNO and STO thin films $(\sim 100 \mathrm{~nm})$ were fabricated by sol-gel/spincoating method on $\mathrm{Al}_{2} \mathrm{O}_{3}$ substrates with PZT interlayer and annealed at $1000^{\circ} \mathrm{C}$. The structural characterization of the SNO film demonstrated different phase formation with orthorhombic O- $\mathrm{SmNbO}_{4}$ and monoclinic $\mathrm{M}-\mathrm{SmNbO}_{4}$. XRD results confirmed the presence of single monoclinic $\mathrm{M}^{\prime}-\mathrm{SmTaO}_{4}$ phase in STO thin film. In heterogeneous microstructure of SNO film were identified spherical $\mathrm{O}-\mathrm{SmNbO}_{4}$ and cuboidal $\mathrm{M}-\mathrm{SmNbO}_{4}$ particles, which is difference as compared with the $\mathrm{SmTaO}_{4}$ film composed of spherical particles (single monoclinic $\mathrm{M}^{\prime}-\mathrm{SmTaO}_{4}$ phase). This study indicated that $\mathrm{Nb}^{5+}$ or $\mathrm{Ta}^{5+}$ and $\mathrm{Sm}$ element are directly correlated with the crystalline arrangement of the niobate and tantalate thin films. The results of this work can contribute to the fabrication of these films for the application to environmental electrolytic thin film devices.

\section{Acknowledgement}

This work was supported by the Grant Agency of the Slovak Academy of Sciences through project No. 2/0036/17. 


\section{REFERENCES}

[1] Mather, SA., Davies, PK.: J. Am. Ceram. Soc., vol. 78, 1995, p. 2737

[2] Loiko, PA., Dymshits, OS., Alekseeva, IP., Zhilin, AA., Tsenter, MY., Vilejshikova, EV., Bogdanov, KV., Mateos, X., Yumashev, KV.: J. Luminesc., vol. 179, 2016, p. 64

[3] Zhang, P., Song, Z., Wang, Y., Han, Y., Dong, H., Li, L.: J. Alloys Compd., vol. 581, 2013, p. 741

[4] Hirano, M., Dozono, H.: Mater. Res. Bull., vol. 50, 2014, p. 213

[5] Nico, C., Soares, MRN., Costa, FM., Monteiro, T., Graça, MPF.: J. Appl. Phys., vol. 120, 2016, p. 051708

[6] Kim, SJE., Kim, S.: Ceram. Int., vol. 35, 2009, p. 137

[7] Siqueira, KPF., Carmo, AP., Bell, MJV., Dias, A.: J. Luminesc., vol. 179, 2016, p. 146

[8] Wang, S., Jiang, M., Gao, L., Ma, Z., Wang, F.: Materials, vol. 9, 2016, p. 55

[9] Ramarao, SD., Murthy, VRK.: Phys. Chem. Chem. Phys., vol. 17, 2015, p. 12623

[10] Chou, PH., Chung, YT., Hsieh, ChW., Hsu, ChH.: J. Nanosci. Nanotechnol., vol. 16, 2016, p. 12914

[11] Haugsrud, R., Norby, T.: Nat. Mater., vol. 5, 2006, p. 193

[12] Bozza, F., Schafbauer, W., Meulenberg, WA., Bonanos, N.: Int. J. Hydrogen Energy, vol. 37, 2012, p. 8027

[13] Hardi, M.: Aldrich ${ }^{\circledR}$ Materials Science, (http://www.sigmaaldrich.com/technicalcuments/articles/materials-science/thin-film-solid-oxide-fuel-cells.html).

[14] Peng, H., Zhang, Y., Zhou, YC.: Prog. Nat. Sci: Mater. Int., vol. 22, 2012, p. 219

[15] Pontes, DSL., Pontes, FM., Pereira-da-Silva, MA., Zampieri, M., Chiquito, AJ., Pizani, PS., Longo, E.: Ceram. Int., vol. 40, 2014, p. 4085

[16] Velu, G., Haccart, T., Jaber, B., Remiens, D.: J. Vac. Sci. Technol. A, vol. 16, 1998, p. 2442

[17] Li, DH., Lee, ES., Chung, HW., Lee, SY.: Appl. Surf. Sci., vol. 252, 2006, p. 4541

[18] Fernandez, F., Moure, C., Villegas, M., Duran, P., Kosec, M., Drazic, G.: J. Eur. Ceram. Soc., vol. 18, 1998, p. 1695

[19] Zheng, H., Reaney, IM., Lee, WE.: J. Am. Ceram. Soc., vol. 85, 2002, p. 207

[20] Carim, AH.: J. Am. Ceram. Soc., vol. 74, 1991, p. 1455

[21] Brennecka, GL., Parish, ChM., Tuttle, BA., Brewer, LN., Rodriguez, MA.: Adv. Mater., vol. 20, 2008, p. 1407

[22] Brunckova, H., Medvecky, L., Briancin, J., Durisin, J., Mudra, E., Sebek, M., Kovalcikova, A., Sopcak, T., Mater. Lett., vol. 165, 2016, p. 239

[23] Brunckova, H., Medvecky, L., Briancin, J., Saksl, K.: Ceram. Int., vol. 30, 2004, p. 453

[24] Siqueira, KPF., Moreira, RL., Dias, A.: Chem. Mater., vol. 22, 2010, p. 2668

[25] Siqueira, KPF., Carvalho, GB., Dias, A.: Dalton Trans., vol. 40, 2011, p. 9454

[26] Graca, MPF., Peixoto, MV., Ferreira, N., Rodrigues, J., Nico, C., Costa, FM., Monteiro, T.: J. Mater. Chem., vol. C 1, 2013, p. 2913

[27] Freiria, GS., Nassar, EJ., Verelst, ML., Rocha, A.: J. Luminesc., vol. 169, 2016, p. 844

[28] Hirano, M., Ishikawa, K.: J. Ceram. Soc. Japan, vol. 124, 2016, p. 42

[29] Ilhan, M., Ekmekçi, MK., Mergen, A., Yaman, C.: J. Fluoresc., vol. 26, 2016, p. 1671

[30] Xiao, X., Yan, B.: J. Mater. Res., vol. 23, 2008, p. 679

[31] Wang, J., Chong, X., Zhou, R., Feng, J.: Scripta Mater., vol. 126, 2017, p. 24

[32] Gu, M., Zhu, L., Liu, X., Huang, S., Liu, B., Ni, Ch.: J. Alloys Compd., vol. 501, 2010, p. 371

[33] Natali, M., Garoli, D., Rigato, V., Romanato, F.: J. Vac. Sci. Technol., vol. A 29, 2011, p. 061505

[34] Lima, EC., Araujo, EB.: Adv. Mater. Phys. Chem., vol. 2, 2012, p. 178 
[35] Zhang, H., Moilanen, H., Uusi, A., Leppavuori, S., Rautioaho, R.: J. Electron. Mater., vol. 22, 1993, p. 419 